УДК 37.015.31-053.6:316.42]:005.3362

DOI: 10.37026/2520-6427-2020-102-2-161-167
Наталія СУШИК,

кандидат педагогічних наук, дочент кафедри сочіальної роботи та педагогіки вищої школи

Східноєвропейського національного університету імені Лесі Українки, м. Луиьк

\title{
КОМПЕТЕНТНІСНИЙ ПІДХІД У РЕАЛІЗАЦЇ̈ ТЕХНОЛОГІЇ СОЦІАЛЬНОГО ВИХОВАННЯ «ОСОБИСТА ГІДНІСТЬ. БЕЗПЕКА ЖИТТЯ. ГРОМАДЯНСЬКА ПОЗИЦІЯ» ДІТЕЙ ПІДЛІТКОВОГО ТА ЮНАЦЬКОГО ВІКУ
}

У статті обтрунтовано компетентність як здатність особистості активізувати, мобілізувати, ефективно застосувати изінності, иіннісні орієнтації, знання, переконання, вміння, навички відповідно до вимог, викликів, можливостей у визначеному контексті. Окреслено сутність, зміст, етапи формування життєвої, комунікативної, правової, соиіальної, економічної, дозвіллєвої компетентностей особистості. Визначено об'єкт, суб'єкт, мету, завдання, структуру, зміст, етапи, форми, методи реалізачії технологї сочіального виховання "Особиста гідність. Безпека життя. Громадянська позииія» дітей підліткового та юнацького віку на основі компетентнісного підходу.

Ключові слова: сочіальне виховання, технологія соиіального виховання "Особиста гідність. Безпека життя. Громадянська позиція» дітей підліткового та юнацького віку, компетентнісний підхід, компетентність, життєва, комунікативна, правова, сочіальна, економічна, дозвіллєва компетентності, цінність, ціннісна орієнтація, знання, ставлення, переконання, вміння, навички особистості.

В статье обоснована компетентность как способность личности активизовать, мобилизовать, эффективно применить иенности, ценностные ориентации, знания, убеждения, умения, навыки в соответствии с условиями, требованиями в определенном контексте. Очерчены сущность, содержание, этапы формирования жизненной, коммуникативной, правовой, сочиальной, экономической, досуговой компетентностей личности определены на основе новой кониептуальной модели. Охарактеризована технология сочиального воспитания «Личное достоинство. Безопасность жизни. Гражданская позищия» детей подросткового и юношеского возраста на основе компетентностного подхода. Определены объект, субъект, иели, задачи, структура, содержание, этапь, формы, методы реализации этой технологии.

Ключевые слова: сочиальное воспитание, технология соииального воспитания «Личное достоинство. Безопасность жизни. Гражданская позиция» детей подросткового и юношеского возраста, компетентностный подход, компетентность, жизненная, коммуникативная, правовая, сочиальная, экономическая, досуговая компетентности, иенность, иенностная ориентация, знания, отношение, убеждения, умения, навыки личности.

Competent method in realization of technology of social education "Personal dignity. Safety of life. Social position» of children in teenage and young adult age. This article describes competence as an ability of personality to activate and affectively apply values, directions of values, knowledge, beliefs, skills according to obligations and abilities in definition of competence. Defined essence and definition of communicative, legal, social, economical and every day life competence of personality.

Development of this competence of personality in a process of realization of technology of social education «Personal dignity. Safety of life. Social position» of teenagers and young adults presented through this steps:

1. Forming of values, valuable directions, the knowledge of the norms, rules of behavior of the personality in society.

2. Forming of conscious and responsible treatment of personality to values, valuable orientations, knowledge of norms and the rules of behavior on society.

3. Forming of personal desire of personality to live based of values of society.

4. Forming of skills of personality to apply knowledge in every day life.

5. Forming of an ability of the personality to activate and cultivate and affectedly apply of values, knowledge, skills in the defined conditions.

The article defines the objects, essence and purpose, structure, contest and steps and methods of technology of social education "Personal dignity. Safety of life. Social position» of children and teenagers based on competent strategy.

Key words: social education, technology of social education «Personal dignity. Safety of life. Social position» of children and teenagers, competent method, competence: communicative, legal, social, economical, ethical. 
Постановка проблеми. Технологія соціального виховання «Особиста гідність. Безпека життя. Громадянська позиція» дітей підліткового та юнацького віку, розроблена на основі компетентнісного підходу, - інноваційний підхід до визначення та реалізації мети, завдання, змісту, етапів, форм, методів, засобів соціального виховання, зорієнтований на результат розвиток і формування компетентної особистості.

Соціальне виховання (у вузькому значенні) - це цілеспрямований виховний вплив на свідомість, поведінку особистості з метою розвитку, формування компетентної особистості, зокрема життєвої, здоров'язбережувальної, комунікативної, правової, соціальної, економічної, дозвіллєвої та інших компетентностей.

Нова концептуальна модель компетентностей особистості, необхідних для повноцінної участі в демократичних процесах та мирного співжиття з іншими людьми в культурно багатоманітних суспільствах, розроблена Радою Свропи у 2016 році [2, с. 35-55]. Згідно з цією моделлю термін "компетентність" трактується як здатність особистості активізувати, мобілізувати, ефективно застосувати цінності, иіннісні орієнтації, знання, переконання, вміння, навички відповідно до вимог, викликів, можливостей у визначеному контексті [2, с. 23].

На основі вивчення міжнародних і вітчизняних законодавчих документів, наукової соціально-педагогічної літератури щодо сутності, структури та змісту компетентностей особистості пропонуємо такі визначення понять:

- життсва компетентність - здатність особистості успішно вирішувати актуальні завдання на різних вікових етапах в усіх сферах життєдіяльності, спрямовувати соціальні та особистісні ресурси на самовдосконалення (самопізнання, саморозвиток, самоосвіту, самовиховання);

- комунікативна компетентність - здатність особистості толерантно й ефективно спілкуватися 3 людьми в різних життєвих ситуаціях;

- правова компетентність - здатність особистості відповідально, ефективно реалізовувати права та обов'язки в усіх сферах життєдіяльності;

- соиіальна компетентність - здатність особистості ефективно співпрацювати з партнерами у групі, команді, колективі, виконувати різні соціальні ролі та функції («громадянина», «працівника», «учня», «студента», «чоловіка/дружини», «батька/матері» та інші);

- економічна компетентність - здатність особистості відповідально заробляти, зберігати, заощаджувати, раціонально використовувати фінансові, матеріальні, особистісні, сімейні, суспільні ресурси;

- дозвіллєва компетентність - здатність особистості ефективно й оптимально використовувати вільний час, цікаво, змістовно організовувати дозвіллєву та творчу діяльність.

Аналіз наукових досліджень і публікацій. Із метою обгрунтування компетентнісного підходу в реалізації технології соціального виховання «Особиста гідність. Безпека життя. Громадянська позиція» дітей підліткового та юнацького віку нами було проаналізовано наукові праці в таких аспектах: сутність, особливості, мета, завдання, зміст, структура, форми, методи, засоби виховання особистості; сутність, особливості, етапи технологій виховання особистості (I. П. Підласий) [5]; нова концептуальна модель компетентностей особистості, необхідних для повноцінної участі в демократичних процесах і мирного співжиття 3 іншими людьми в культурно багатоманітних суспільствах, розроблена Радою Свропи у 2016 р. [2]; програма виховної роботи з учнями з питань протидії торгівлі людьми «Особиста гідність. Безпека життя. Громадянська позиція» (Т. П. Авельцева, А. В. Гулевська-Черниш, І. Д. Звєрєва, Н. В. Зимівець, Т. Л. Лях, Н. О. Москвіна, В. С. Петрович, Ж. В. Петрочко, Т. П. Цюман та ін.) [4].

Мета статті - обгрунтувати застосування компетентнісного підходу в ході реалізації технології соціального виховання «Особиста гідність. Безпека життя. Громадянська позиція» дітей підліткового та юнацького віку.

Виклад основного матеріалу. Технологія соціального виховання «Особиста гідність. Безпека життя. Громадянська позиція» спрямована на розвиток, формування компетентної особистості, здатної гідно та відповідально здобувати освіту, професію, спілкуватися, здійснювати інші види діяльності в сучасних умовах та майбутньому. Завданнями цієї технології є розвиток, формування компетентностей (життєвої, комунікативної, правової, соціальної, економічної, дозвіллєвої) дітей підліткового та юнацького віку.

На нашу думку, розвиток, формування компетентностей (життєвої, комунікативної, правової, соціальної, економічної, дозвіллєвої) особистості в ході реалізації технології соціального виховання «Особиста гідність. Безпека життя. Громадянська позиція» дітей підліткового та юнацького віку передбачає такі послідовні етапи:

1. Формування цінностей (наприклад, життя, особиста гідність, освіта, професія, сім'я, батьківство, добробут, дозвілля, дружба, лідерство, громадянство тощо), ціннісних оріснтацій (зокрема, гідне, безпечне, комфортне життя, якісна освіта, конкурентоздатна професія, компетентна професійна діяльність, успішна професійна кар'єра, благополучна сім'я, усвідомлене, відповідальне, компетентне батьківство, цікаве, змістовне, безпечне дозвілля, безкорисна дружба, відповідальне лідерство, громадянство та ін.), знань про норми, правила поведінки особистості в суспільстві.

цінності - предмети та явища, або їх властивості, що мають певне значення для особистості та задовольняють іiі потреби, інтереси, бажання.

Ціннісні орієнтації - мотивація активності, спрямованість діяльності особистості.

Знання - осмислена та засвоєна суб' єктом інформація, що є основою його усвідомленої, цілеспрямованої діяльності [3].

2. Формування усвідомленого та відповідального ставлення особистості до цінностей, ціннісних орієнтацій, знань про норми, правила поведінки в суспільстві.

Ставлення - така ментальна спрямованість, якої особистість набуває щодо об'єкта (наприклад, людини, групи, інституції, ситуації, події, символу). Ставлення зазвичай має чотири компоненти: 1) інформація про об'єкт; 2) оцінювання (позитивне або негативне) об'єкта; 3) емоція або почуття до об'єкта; 4) намір поводитися в особливий спосіб щодо об'єкта [2, с. 39].

3. Формування переконання особистості здійснювати свою життедіяльність на основі цінностей, ціннісних орієнтацій, знань про норми, правила поведінки в суспільстві.

Переконання - стійкі світоглядні погляди особистості, що базуються на певних принципах і слугують керівництвом у житті.

4. Формування умінь, навичок особистості застосовувати знання для цілеспрямованого, ефективного виконання діяльності. 
Уміння - засвоєний людиною спосіб виконання діяльності, що забезпечується сукупністю набутих знань [7, с. 223].

Навички - дії, сформовані шляхом повторення, що характеризуються високим ступенем засвоєння і відсутністю свідомої регуляції та контролю [6, c. 226].

5. Формування здатності особистості активізувати, мобілізувати, ефективно застосувати цінності, ціннісні орієнтації, знання, переконання, уміння, навички у визначених умовах.

Із метою обміну досвідом педагогічних працівників та фахівців із соціальної роботи щодо ефективної реалізації технології соціального виховання «Особиста гідність. Безпека життя. Громадянська позиція» дітей підліткового та юнацького віку пропонуємо іiі характеристику на основі компетентнісного підходу (див. табл.).

Таблиияя

Характеристика технології соціального виховання «Особиста гідність. Безпека життя. Громадянська позиція» дітей підліткового та юнацького віку на основі компетентнісного підходу

\begin{tabular}{|c|c|c|c|}
\hline $\begin{array}{l}\text { № } \\
\text { 3/II }\end{array}$ & Компоненти технології & \multicolumn{2}{|r|}{$\begin{array}{c}\text { Характеристика } \\
\text { компонентів технології }\end{array}$} \\
\hline 1 & Об’єкт технології & \multicolumn{2}{|c|}{$\begin{array}{l}\text { учні 7-11 класів (діти підліткового та юнацького віку) закладів } \\
\text { загальної середньої, позашкільної освіти, батьки учнів }\end{array}$} \\
\hline 2 & Суб’скти реалізацї технології & \multicolumn{2}{|c|}{$\begin{array}{l}\text { соціальні педагоги, педагоги закладів загальної середньої, } \\
\text { позашкільної освіти, фахівці із соціальної роботи }\end{array}$} \\
\hline 3 & Мета технології & \multicolumn{2}{|c|}{$\begin{array}{l}\text { розвиток, формування компетентної особистості, здатної гідно та } \\
\text { відповідально здобувати освіту, професію, спілкуватися, здійс- } \\
\text { нювати інші види діяльності в сучасних умовах та майбутньому }\end{array}$} \\
\hline 4 & Завдання технології & \multicolumn{2}{|c|}{$\begin{array}{l}\text { формування компетентностей (життєвої, комунікативної, право- } \\
\text { вої, соціальної, економічної, дозвіллєвої) дітей підліткового та } \\
\text { юнацького віку }\end{array}$} \\
\hline \multirow[t]{4}{*}{5} & \multirow[t]{4}{*}{ Структура технології } & \multicolumn{2}{|c|}{ Блок 1. Ставлення до себе } \\
\hline & & \multicolumn{2}{|c|}{ Блок 2. Ставлення до інших } \\
\hline & & \multicolumn{2}{|c|}{ Блок 3. Ставлення до діяльності } \\
\hline & & \multicolumn{2}{|c|}{ Блок 4. Ставлення до навколишнього світу } \\
\hline \multirow[t]{15}{*}{6} & Зміст технології & \multicolumn{2}{|c|}{$\begin{array}{l}\text { 1) формування жситтсвої компетентності дітей } \\
\text { підліткового та юнацького віку }\end{array}$} \\
\hline & \multirow{6}{*}{$\begin{array}{l}\text { Тема 1. «Грані особистості». } \\
\text { Тема 2. «Бути собою» . } \\
\text { Тема 3. «Як поважати себе» (ч.1-2). } \\
\text { Тема 4. «Усі ми різні - усі ми рівні». } \\
\text { Тема 6. «Стереотипи та } \\
\text { упередження» (ч.1-2) (для учнів } \\
7 \text { кл.). } \\
\text { Тренінг 1. «Особиста гідність» (ч.1- } \\
\text { 2) (для учнів } 11 \text { кл.) }\end{array}$} & цінність & особиста гідність \\
\hline & & $\begin{array}{l}\text { ціннісна } \\
\text { орієнтація }\end{array}$ & повага самого себе та інших людей \\
\hline & & знання & $\begin{array}{l}\text { індивідуальність, відмінність, рівність, толерант- } \\
\text { ність людей, особистість, гідність, особиста гідність, } \\
\text { повага, самоповага, образ (імідж) людини та його } \\
\text { складові }\end{array}$ \\
\hline & & переконання & $\begin{array}{l}\text { толерантне ставлення до інших людей, кожна лю- } \\
\text { дина заслуговує на повагу }\end{array}$ \\
\hline & & $\begin{array}{l}\text { уміння, } \\
\text { навички }\end{array}$ & поважати особисту гідність та інших людей \\
\hline & & здатність & $\begin{array}{l}\text { поводитися гідно та толерантно в різних життєвих } \\
\text { ситуаціях }\end{array}$ \\
\hline & \multirow{6}{*}{$\begin{array}{l}\text { Tема 1. «Життєві цінності» (ч. 1-2). } \\
\text { Тема 2. «Життя як цінність» (ч. 1-2) } \\
\text { (для учнів } 9 \text { кл.). } \\
\text { Тема 7. «Безпека - небезпека» (ч. 1- } \\
\text { 2) (для учнів } 7 \text { кл.). } \\
\text { Тема 3. «Спілкування у безпечному } \\
\text { Інтернеті». } \\
\text { Тема 7. «Торгівля дітьми як небез- } \\
\text { пека життя» (ч. 1-2) (для учнів } 8 \text { кл.). } \\
\text { Тема 7. «Поїздка за кордон: } \\
\text { за і проти» (для учнів } 10 \text { кл.). } \\
\text { Тренінг 2. «Безпека життя» (ч. 1-3) } \\
\text { (для учнів } 11 \text { кл.) }\end{array}$} & цінність & життя \\
\hline & & $\begin{array}{c}\text { ціннісна } \\
\text { орієнтація }\end{array}$ & безпечне, комфортне життя \\
\hline & & знання & $\begin{array}{l}\text { стиль життя, рівень життя, якість життя, безпека } \\
\text { життя, ризик, небезпека, небезпечна ситуація, нор- } \\
\text { ми та правила безпечної поведінки }\end{array}$ \\
\hline & & переконання & формувати безпечний, комфортний стиль життя \\
\hline & & $\begin{array}{c}\text { уміння, } \\
\text { навички }\end{array}$ & безпечної поведінки в різних ситуаціях \\
\hline & & здатність & поводитися безпечно в різних ситуаціях \\
\hline & \multirow{2}{*}{$\begin{array}{l}\text { Тема 1. «Розуміти себе» (ч. 1-3) } \\
\text { (для учнів } 8 \text { кл.). } \\
\text { Тема 1. «Думки про щастя». }\end{array}$} & цінність & життєве самовизначення особистості \\
\hline & & $\begin{array}{l}\text { ціннісна } \\
\text { орієнтація }\end{array}$ & успішне, щасливе життя \\
\hline
\end{tabular}


Продовження таблищі

\begin{tabular}{|c|c|c|c|}
\hline \multirow[t]{5}{*}{$\begin{array}{l}\text { № } \\
\text { 3/II }\end{array}$} & \multirow{5}{*}{\begin{tabular}{l}
\multicolumn{1}{c}{ Компоненти технології } \\
Тема 2. «Творець своєї долі» (ч. 1-3) \\
(для учнів 10 кл.). \\
Тренінг 1. «Особиста гідність» (ч. 3) \\
(для учнів 11 кл.)
\end{tabular}} & \multicolumn{2}{|r|}{$\begin{array}{c}\text { Характеристика } \\
\text { компонентів технології }\end{array}$} \\
\hline & & знання & $\begin{array}{l}\text { сутність та особливості самопізнання, програма } \\
\text { особистісного зростання, самоаналіз, самооцінка, } \\
\text { самоконтроль }\end{array}$ \\
\hline & & переконання & $\begin{array}{l}\text { самореалізація на основі самопізнання та самовиз- } \\
\text { начення особистості }\end{array}$ \\
\hline & & $\begin{array}{l}\text { уміння, } \\
\text { навички }\end{array}$ & $\begin{array}{l}\text { об’єктивно оцінювати себе, узгоджувати свої по- } \\
\text { треби з власними можливостями, визначати та до- } \\
\text { сягати життєві цілі, здобувати результати }\end{array}$ \\
\hline & & здатність & $\begin{array}{l}\text { досягати успіху на основі самопізнання та само- } \\
\text { визначення особистості }\end{array}$ \\
\hline \multirow{6}{*}{\multicolumn{2}{|c|}{$\begin{array}{l}\text { Тема 9. «Як приймати рішення» } \\
\text { (ч. 1-2) } \\
\text { Тема 10. «Коло мого життєвого } \\
\text { досвіду» (ч. 1-2) (для учнів } 7 \text { кл.). } \\
\text { Тема 6. «Розв’язання складних } \\
\text { ситуацій (проблем)» (ч. 1-3) (для } \\
\text { учнів } 8 \text { кл.) } \\
\text { Тема 5. «Протидія негативним } \\
\text { явищам у суспільстві» (ч. 1-2) (для } \\
\text { учнів } 10 \text { кл.) }\end{array}$}} & цінність & життсвий досвід \\
\hline & & $\begin{array}{l}\text { ціннісна } \\
\text { орієнтація }\end{array}$ & здобуття якісного життєвого досвіду \\
\hline & & знання & $\begin{array}{l}\text { причини та види проблем, алгоритм прийняття від- } \\
\text { повідальних рішень, джерела здобуття життєвого } \\
\text { досвіду }\end{array}$ \\
\hline & & переконання & особиста відповідальність за ухвалене рішення \\
\hline & & $\begin{array}{c}\text { уміння, } \\
\text { навички } \\
\end{array}$ & прийняття відповідальних рішень \\
\hline & & здатність & $\begin{array}{l}\text { приймати відповідальні рішення в різних житте- } \\
\text { вих ситуаціях }\end{array}$ \\
\hline & \multirow{7}{*}{$\begin{array}{l}\text { Тема 8. «Моя поведінка в конфлікті } \\
\text { / небезпечній ситуації» (для } \\
\text { учнів } 7 \text { кл.). } \\
\text { Тема 3. «Як будувати стосунки } 3 \\
\text { іншими» (ч. 1-2). } \\
\text { Тема 4. «Як протидіяти тиску/як } \\
\text { сказати «ні»» (ч. 1-2) (для учнів } \\
9 \text { кл.) }\end{array}$} & \multicolumn{2}{|c|}{$\begin{array}{l}\text { 2) формування комунікативної компетентності дімей підліт- } \\
\text { кового та юнацького віку }\end{array}$} \\
\hline & & цінність & спілкування \\
\hline & & $\begin{array}{l}\text { ціннісна } \\
\text { оріснтація }\end{array}$ & толерантне, ефективне спілкування \\
\hline & & знання & $\begin{array}{l}\text { види, функції, стилі спілкування; причини виник- } \\
\text { нення, стадії розвитку конфліктів, алгоритми, } \\
\text { методи, засоби їх ефективного розв’язання }\end{array}$ \\
\hline & & переконання & $\begin{array}{l}\text { толерантне, ефективне спілкування } 3 \text { різними } \\
\text { людьми }\end{array}$ \\
\hline & & $\begin{array}{l}\text { уміння, } \\
\text { навички }\end{array}$ & $\begin{array}{l}\text { ефективно застосовувати стилі, вербальні та невер- } \\
\text { бальні засоби спілкування; здійснювати саморегу- } \\
\text { ляцію емоцій і почуттів, встановлювати психо- } \\
\text { логічний контакт зі співрозмовником; активно слу- } \\
\text { хати співрозмовника; здійснювати переконливий } \\
\text { вплив на нього; співчувати та співпереживати; } \\
\text { попереджувати, конструктивно розв'язувати конф- } \\
\text { лікти взаємодії }\end{array}$ \\
\hline & & здатність & $\begin{array}{l}\text { толерантно, ефективно спілкуватися } 3 \text { різними } \\
\text { людьми }\end{array}$ \\
\hline & \multirow{7}{*}{$\begin{array}{l}\text { Тема 11. «Мої права та обов’язки» } \\
\text { (ч. 1-2) (для учнів } 7 \text { кл.). } \\
\text { Тема 9. «Міжнародна солідарність } \\
\text { проти найгірших форм дитячої } \\
\text { праці» (для учнів } 8 \text { кл.). } \\
\text { Тема 4. «Торгівля людьми як } \\
\text { порушення прав людини» (ч. 1-2). } \\
\text { Тема 8. «Міжнародне законодавство } \\
\text { щодо протидії торгівлі людьми, } \\
\text { різних форм експлуатації» (для учнів } \\
10 \text { кл.) }\end{array}$} & \multicolumn{2}{|c|}{$\begin{array}{l}\text { 3) формування правової компетентності дітей підліткового } \\
\text { та юнацького віку }\end{array}$} \\
\hline & & цінність & права людини і дитини \\
\hline & & $\begin{array}{l}\text { ціннісна } \\
\text { орієнтація }\end{array}$ & реалізація, захист прав людини і дитини \\
\hline & & знання & $\begin{array}{l}\text { правоздатність, види, зміст прав дитини; дієздат- } \\
\text { ність, правові норми, правила, обов'язок, відпові- } \\
\text { дальність, види відповідальності малолітньої та } \\
\text { неповнолітньої дитини }\end{array}$ \\
\hline & & переконання & $\begin{array}{l}\text { дотримуватися правових норм і правил поведінки } \\
\text { в різних життєвих ситуаціях }\end{array}$ \\
\hline & & $\begin{array}{l}\text { уміння, } \\
\text { навички }\end{array}$ & реалізувати, захищати права людини та дитини \\
\hline & & здатність & $\begin{array}{l}\text { відповідально поводитися згідно з правовими нор- } \\
\text { мами і правилами в різних життєвих ситуаціях }\end{array}$ \\
\hline
\end{tabular}


Продовження таблицุi

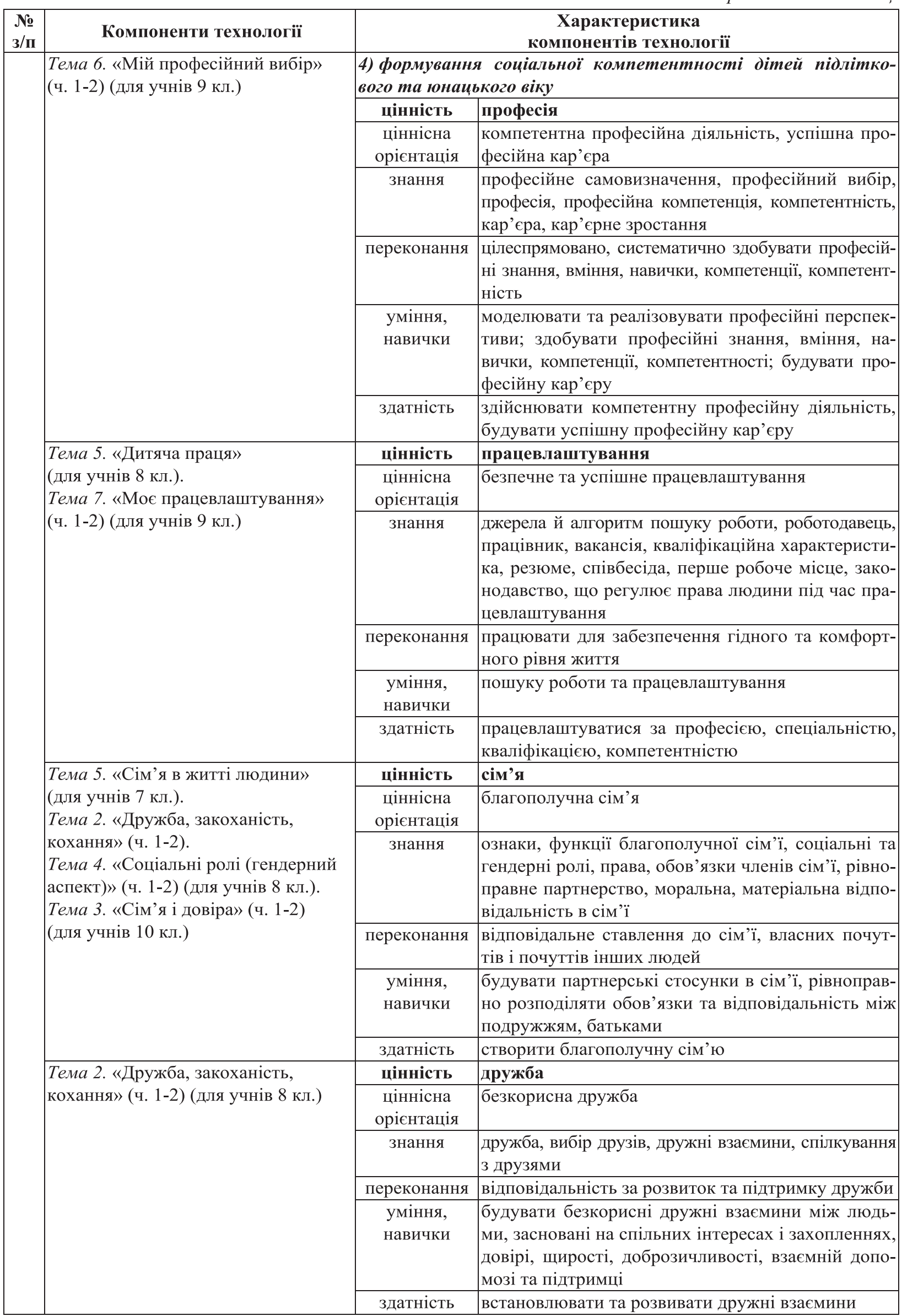


Продовження таблиичі

\begin{tabular}{|c|c|c|c|}
\hline $\begin{array}{l}\text { № } \\
\text { 3/II }\end{array}$ & Компоненти технології & \multicolumn{2}{|r|}{$\begin{array}{c}\text { Характеристика } \\
\text { компонентів технології }\end{array}$} \\
\hline & \multirow{6}{*}{$\begin{array}{l}\text { Тема 12. «Я громадянин світу» (для } \\
\text { учнів } 7 \text { кл.). } \\
\text { Тема 8. «Розмаїття та єдність світу» } \\
\text { (ч. 1-2) (для учнів } 8 \text { кл.). } \\
\text { Тема 9. «Суспільство і я» (ч. 1-3) } \\
\text { (для учнів } 9 \text { кл.). } \\
\text { Тема 9. «Міжнародне співтовариство } \\
\text { у боротьбі проти торгівлі людьми» } \\
\text { (для учнів } 10 \text { кл.). } \\
\text { Тренінг 3. «Громадян- } \\
\text { ська позиція» (ч. 1-3) (для учнів } \\
11 \text { кл.) }\end{array}$} & цінність & громадянство \\
\hline & & $\begin{array}{c}\text { ціннісна } \\
\text { орієнтація }\end{array}$ & відповідальне громадянство \\
\hline & & знання & $\begin{array}{l}\text { соціальна роль «громадянин», права та обов'язки } \\
\text { громадянина, громадянськість, громадянська пози- } \\
\text { ція }\end{array}$ \\
\hline & & переконання & відповідальний, ініціативний, активний громадянин \\
\hline & & $\begin{array}{l}\text { уміння, } \\
\text { навички }\end{array}$ & $\begin{array}{l}\text { розроблення та реалізації соціальних ініціатив, } \\
\text { проєктів у громаді, організації активної громадян- } \\
\text { ської діяльності }\end{array}$ \\
\hline & & здатність & $\begin{array}{l}\text { відповідально реалізовувати громадянські права } \\
\text { та виконувати громадянські обов'язки }\end{array}$ \\
\hline & $\begin{array}{l}\text { Тема 5. «Мій добробут» (ч. 1-2) } \\
\text { (для учнів } 9 \text { кл.) }\end{array}$ & \multicolumn{2}{|c|}{$\begin{array}{l}\text { 4) формування економічної компетентності дітей підлітко- } \\
\text { вого та юнацького віку }\end{array}$} \\
\hline & & цінність & добробут \\
\hline & & $\begin{array}{c}\text { ціннісна } \\
\text { орієнтація }\end{array}$ & добробут, благополуччя \\
\hline & & знання & $\begin{array}{l}\text { благополуччя людини, особистий, сімейний добро- } \\
\text { бут, особистий, сімейний бюджет, раціональне та } \\
\text { нераціональне використання ресурсів, витрати, } \\
\text { збереження, заощадження }\end{array}$ \\
\hline & & переконання & $\begin{array}{l}\text { особиста відповідальність за використання фінан- } \\
\text { сових, матеріальних та інших ресурсів }\end{array}$ \\
\hline & & $\begin{array}{l}\text { уміння, } \\
\text { навички }\end{array}$ & $\begin{array}{l}\text { планувати й складати особистий, сімейний бю- } \\
\text { джет; відповідально використовувати фінансові, } \\
\text { матеріальні, природні, суспільні ресурси }\end{array}$ \\
\hline & & здатність & забезпечувати гідний та комфортний рівень життя \\
\hline & $\begin{array}{l}\text { Тема 8. «Моє дозвілля» } \\
\text { (для учнів } 9 \text { кл.). }\end{array}$ & \multicolumn{2}{|c|}{$\begin{array}{l}\text { 5) формування дозвіллсвої компетентності дітей підлітко- } \\
\text { вого та юнацького віку }\end{array}$} \\
\hline & Тема 6. «Безпечне та корисне & цінність & дозвілля \\
\hline & дозвілля» (ч. 1-2) (для учнів 10 кл.) & $\begin{array}{l}\text { ціннісна } \\
\text { орієнтація }\end{array}$ & цікаве, змістовне, безпечне дозвілля \\
\hline & & знання & $\begin{array}{l}\text { сутність, функції, види, рівні, зміст, форми дозвілля } \\
\text { особистості }\end{array}$ \\
\hline & & переконання & $\begin{array}{l}\text { різноманітне, цікаве, змістовне, безпечне дозвілля } \\
\text { підвищує рівень соціальної компетентності осо- } \\
\text { бистості }\end{array}$ \\
\hline & & $\begin{array}{l}\text { уміння, } \\
\text { навички }\end{array}$ & організовувати особисте та сімейне дозвілля \\
\hline & & здатність & $\begin{array}{l}\text { цікаво, змістовно, раціонально організовувати осо- } \\
\text { бисте та сімейне дозвілля }\end{array}$ \\
\hline 7 & Форми реалізації технології & \multicolumn{2}{|c|}{$\begin{array}{l}\text { тематичні виховні години, відеолекторій, тренінги, тренінгові } \\
\text { заняття, ігрові заняття з використанням настільних ігор [1, с. 36-44], } \\
\text { практичні заняття } 3 \text { використанням коміксів [1, с. 45-48], кон- } \\
\text { курс плакатів [1, с. 49-51] }\end{array}$} \\
\hline 8 & Методи реалізації технології & \multicolumn{2}{|c|}{$\begin{array}{l}\text { бесіда, мозковий штурм, інформаційне повідомлення, дискусія, } \\
\text { переконання, приклад, робота в малих групах, метод вправ, кейс- } \\
\text { метод }\end{array}$} \\
\hline 9 & Тривалість реалізації технології & \multicolumn{2}{|c|}{$\begin{array}{l}\text { для кожного класу тематичні виховні години, розраховані на } 16- \\
19 \text { годин упродовж навчального року }\end{array}$} \\
\hline 10 & \multicolumn{3}{|c|}{$\begin{array}{l}\text { Навчально-методичне забезпечення технології } \\
\text { 1. Особиста гідність. Безпека життя. Громадянська позиція : програма виховної роботи з учнями з питань } \\
\text { протидії торгівлі людьми / наук. кер. та ред. І. Д. Звєрєвої та Ж. В. Петрочко. - К. : ФО-П Буря О.Д., } 2014 . \\
\text { - } 88 \text { с. URL: https://mon.gov.ua/storage/app/media/pozashkilna/Osobysta-gidnist_programa.pdf } \\
\text { (двернення: 29.01.2020). } \\
\text { 2. Особиста гідність. Безпека життя. Громадянська позиція : метод. посіб. для виховної роботи } 3 \\
\text { учнями з питань протидії торгівлі людьми : } 7 \text { клас / наук. кер. та ред. I. Д. Звєрєвої та Ж. В. Петрочко. } \\
\text { - Вид. 3-тє, доповн. - К. : ФО-П Савісько I. С., 2017. - 188 с. URL: https://childfund.org.ua/ } \\
\text { Uploads/Files/books_pdf/osobysta_gidnist_7klas_2017.pdf (дата звернення: 29.01.2020). }\end{array}$} \\
\hline
\end{tabular}


Продовження таблииі

3. Особиста гідність. Безпека життя. Громадянська позиція : метод. посіб. для виховної роботи 3 учнями з питань протидії торгівлі людьми : 8 клас / наук. кер. та ред. І. Д. Звєрєвої та Ж. В. Петрочко. - Вид. 3-тє, доповн. - К. : ФО-П Савісько I. С., 2017. - 168 с. URL: https://childfund.org.ua/ Uploads/Files/books_pdf/osobysta_gidnist_8klas_2017.pdf (дата звернення: 29.01.2020).

4. Особиста гідність. Безпека життя. Громадянська позиція : метод. посіб. для виховної роботи 3 учнями з питань протидії торгівлі людьми : 9 клас / наук. кер. та ред. І. Д. Звєрєвої та Ж. В. Петрочко. - Вид. 3-те, доповн. - К. : ФО-П Савісько I. С., 2017. - 164 с. URL: https://childfund.org.ua/ Uploads/Files/books_pdf/osobysta_gidnist_9klas_2017.pdf (дата звернення: 29.01.2020).

5. Особиста гідність. Безпека життя. Громадянська позиція : метод. посіб. для виховної роботи 3 учнями з питань протидії торгівлі людьми : 10 клас / наук. кер. та ред. І. Д. Звєрєвої та Ж. В. Петрочко. - Вид. 3-те, доповн. - К. : ФО-П Савісько I. С., 2017. - 140 с. URL: https://childfund.org.ua/ Uploads/Files/books_pdf/osobysta_gidnist_10klas_2017.pdf (дата звернення: 29.01.2020).

6. Особиста гідність. Безпека життя. Гррмадянська позиція : метод. посіб. для виховної роботи 3 учнями з питань протидії торгівлі людьми : 11 клас / наук. кер. та ред. І. Д. Звєрєвої та Ж. В. Петрочко. - Вид. 3-те, доповн. - К. : ФО-П Савісько I. С., 2017. - 132 с. URL: https://childfund.org.ua/ Uploads/Files/books_pdf/osobysta_gidnist_11klas_2017.pdf (дата звернення: 29.01.2020).

Творимо разом світ, безпечний для дитини: програма та зміст тренінгових занять для батьків: інфор.метод. матеріали / наук. кер. та ред. І. Д. Звєрєвої. - К. : [б. в.], 2012. - 268 с. URL: https://childfund.org.ua/Uploads/Files/books_pdf/Posibnyk_parent.pdf (дата звернення: 29.01.2020)

Висновки. До основних етапів упровадження технології соціального виховання «Особиста гідність. Безпека життя. Громадянська позиція» дітей підліткового та юнацького віку відносимо такі основні складові [1]:

1. Діагностику доцільності використання технології з метою формування компетентностей (життєвої, комунікативної, правової, соціальної, економічної, дозвіллєвої) дітей підліткового та юнацького віку на локальному, місцевому, регіональному, державному рівнях.

2. Підвищення компетентності педагогічних працівників та фахівців із соціальної роботи з реалізації технології соціального виховання «Особиста гідність. Безпека життя. Громадянська позиція».

3. Забезпечення закладів загальної середньої освіти навчально-методичними матеріалами 3 реалізації технології соціального виховання «Особиста гідність. Безпека життя. Громадянська позиція».

4. Реалізацію технології соціального виховання «Особиста гідність. Безпека життя. Громадянська позиція» на локальному, місцевому, регіональному, державному рівнях.

5. Діагностику результатів реалізації технології соціального виховання «Особиста гідність. Безпека життя. Громадянська позиція».

6. Обмін досвідом педагогічних працівників та фахівців із соціальної роботи щодо ефективної реалізації технології соціального виховання «Особиста гідність. Безпека життя. Громадянська позиція».

Перспективи подальших наших досліджень передбачають обгрунтування компетентнісного підходу в реалізації технології соціального виховання «Професія. Освіта. Кар'єра. Успіх» дітей підліткового та юнацького віку.

\section{СПИСОК ВИКОРИСТАНОЇ ЛІТЕРАТУРИ}

1. Активізація соціальної роботи в місцевих громадах: досвід упровадження освітньо-профілактичного компонента проекту «Попередження торгівлі людьми шляхом розвитку соціальної роботи та мобілізації громад, 2009-2011 роки» / О. В. Безпалько, Т. Г. Веретенко, І. Д. Звєрєва, Ю. В. Малієнко, Ж. В. Петрочко. - К. : ТОВ «Основа», 2012. - 148 с. URL: https://childfund.org.ua/Uploads/Files/books_pdf/book_ TIP prevention.pdf (дата звернення: 29.01.2020).

2. Компетентності для культури демократії - живеморазом якрівноправнігромадяни в культурно багатоманітному демократичному суспільстві (укр. переклад). Страсбург: Видавництво Ради Свропи, 2016, - Осло : Свропейський центр імені Вергеланда, 2018. - 78 с. URL: file:///C:/Users/Sweet/Downloads/kompetentnosti_ kultury demokratiyi ua.pdf (дата звернення: 30.01.2020).

3. Національна рамка кваліфікацій № 1341-2011-п. URL: https://zakon.rada.gov.ua/laws/show/1341-2011-\% D0\%BF\#n12 (дата звернення: 12.01.2020).

4. Особиста гідність. Безпека життя. Громадянська позиція : програма виховної роботи з учнями 3 питань протидії торгівлі людьми / наук. кер. та ред. I. Д. Звєрєвої та Ж. В. Петрочко. - К. : ФО-П Буря О.Д., 2014. - 88 c. URL: https://mon.gov.ua/storage/ app/media/pozashkilna/Osobysta-gidnist_programa.pdf (дата звернення: 29.01.2020).

5. Подласый И. П. Педагогика. Новый курс : учебник для студ. пед. вузов : в 2 кн. Кн. 2. Процесс воспитания / И. П. Подласый. - М. : ВЛАДОС, 1999. - 256 с.

6. Психология : словарь / под общ. ред. А. В. Петровского, М. Г. Ярошевского. - М. : Политиздат, 1990. - C. 226.

7. Словник-довідник для соціальних педагогів та соціальних працівників / за заг. ред. А. Й. Капської, І. М. Пінчук, С. В. Толстоухової. - К., 2000. - С. 223. 